\title{
THE EFFECT OF FIT BETWEEN NATURAL ENVIRONMENTAL APPROACH AND BUSINESS STRATEGY ON PERFORMANCE ${ }^{1}$
}

\author{
Budi Suprapto \\ Faculty of Economics Atma Jaya Yogyakarta University
}

\begin{abstract}
This field study of 83 chemical firms examines the effect of fit between natural environmental approaches and business strategies on performance. Using factor analysis, the study found three approaches to their natural environment: prevention, information, and correction. Moreover using cluster analysis, the sample firms can be grouped into three categories based on business strategy typology: prospector, defender, and reactors.

The findings from regression analysis suggested that prevention, information, and correction approaches insignificantly affect on performance. Compare to reactors, defenders and prospectors realized significant improvements on performance. The prevention has stronger and significant effect on ROA among prospectors than among defenders. The information has stronger and significant effect on sales growth among prospectors than among defenders. However, the significant effects were not found in the interaction between correction and prospectors. Neither was it found between correction and defenders on performance. In general, the results of those findings support the argument that firms benefit from the adoption of environmental policy when natural environmental approaches fit the business strategy.
\end{abstract}

Keywords: Natural Environmental Approach, Business Strategy and Performance

\section{INTRODUCTION}

The natural environment is becoming a crucial issue for the growth and development of business in the 1990's and beyond (Roome, 1994) because of the increasing demand of the society and government regulation to improve environmental performance. It is now well accepted that firms, by doing more than conforming to regulations, can gain competitive advantage through innovation ranging from product and process design to stakeholder value (Porter and van der Linde ,1995).

Slater and Angel (1999) indicated that environmentally linked strategies have positive implications on competitive advantage. Moreover, Sharma and Vredenburg (1998) found that strategies of proactive responsiveness to the natural environment have positive implications for firm competitiveness. Concerning the cost advantage issue, Cristmann (2000) indicated that best practices of environmental practices have a significant effect on cost reduction. The increasing acceptance of ISO 14000 Environmental Management Standards within firms also shows that environmental regulation enhance rather than hurt competitiveness and performance of companies.

Some studies indicated a significant and positive effect of natural environmental approach on firm's performance. Russo and Fouts (1997) found that high level of natural environmental performance is associated with enhanced profitability. Moreover, Klassen and McLaughlin (1996) found a correlation between firm environmental performance and firm financial performance in subsequent time period.

Studies that explicitly recognized the importance of the natural environment and examined its role in strategic management are beginning to appear in the literature (Hart, 1995; Jennings and Zandbergen, 1995; Shrivastava, 1995a,b; Menon and Menon, 1997). Aragon-Correa (1998) found that there is a significant

\footnotetext{
${ }^{1}$ This articled has been presented in the International Conference INRET 2006
} 
relationship between firms' strategic proactivity and their natural environmental development relative to others in their sector. This finding indicated that the companies have to integrate environmental concerns into their business strategies, organizational structure, and corporate culture. Firms must reformulate their business strategies to proactively address many issues regarding the natural environment. Thus, firms with proactive business strategies are also those that respond most decisively toward natural environment challenges and pressures.

This study investigated how Indonesia chemical firms response to their natural environment and business strategy concepts adopted by them to compete in the industry. Moreover, the primary purpose of this study is to analyze the implication of fit between natural environmental approach and business strategy on performance.

The natural environmental protection is becoming a crucial importance issue in the Indonesian chemical industry. The environment protection costs are among the highest of all industries' cost and thus constitute a strategic issue for this industry (Cristmann, P., 2000). Moreover, in the chemical sector, the ecology-economy trade-off is particular steep (Porter and van der Linde, 1995). The use of single industry context reflects the utility of developing of 'industry recipes' to the further understanding of natural environmental approach as well as business strategy concepts.

\section{LITERATURE REVIEW AND HYPOTHESIS}

\subsection{Natural Environmental Approaches and Performance}

Many Scholars indicates that there are at list two methods (approaches) in grouping firms' position in approaching their natural environment: traditional and modern (Bucholz, 1993; Srivastava, 195; Starik and Rand, 1995). Moreover, Aragon-Correa study of CEOs of 210 firms operating in Spain (1998) found three main approaches regarding how firm approach to natural environment: traditional / regulated correction, modern / voluntary prevention, and information and education. The first approach - traditional / regulated correction approach - was based on logical thinking that government could control in various ways in order to impose environmental standards, based on implementation of available implementation technology. The second approach - modern / voluntary prevention - was based on the though that firms generating pollution would pay pollution charges that was set high enough to accomplish the desire level of pollution reduction. The third approach - information and education - was based on the though that people would be more willing to act responsibly toward environment if they have enough knowledge and information about environmental issues.

Drawing on those Aragon-Correa's (1998) natural environmental approaches, the relationship between natural environmental approach and firm performance is based on three arguments.

First, correction approach (traditional method) intends to reduce the cost of production processes and reducing input and waste disposal. This method produce cost reduction advantage that creates the potential to decrease product prices, which result in expanding the market share.

Second, prevention approach (modern approach) focus on redesign packaging and products in more environmentally responsible ways that lead to produces differentiation advantage. Differentiation advantage creates the potential to increase product prices, which result in high revenue.

Third, information method focuses on activities such as marketing, seminar and sponsorship in environmental event that lead to enhance overall reputation or image of the firm. The reputation creates the potential to increase sales growth.

Russo and Fouts (1997) tested a hypothesis that high levels of environmental performance would be positively associated with enhanced profitability. Their argument was based on a resource-based view of the firm. Implementation of a proactive natural environmental management leads firms utilize resources and capabilities in a different way than a compliance. 
They found that high environmental performance produced by proactive environmental management might enhance the profitability of the firm.

\subsection{Business Strategy and Performance}

Miles and Snows (1978) proposed a classification of business strategies of the firms in four archetypes: The Prospector, The Analyzer, The Defender, and The Reactor. Firm following a prospector strategy frequently adds to and changes its products and services, consistently attempting to be first in the market. Such a firm tends to stress innovation and flexibility in order to be able to respond quickly to changing market conditions. An analyzer's strategy tends to emphasize formal planning processes and tries to balance cost containment and efficiency with risk-taking attitudes and innovation. A defender's strategy is to offer a relatively stable set of services to defined markets, concentrating on doing the best job possible in its area of expertise. It emphasizes tight control and continually looks for operating efficiencies to lower costs. A reactor essentially lacks a consistent strategy. Its strategy has characteristics of each of the other types of strategies at different times and thus is difficult to categorize clearly. It can be summarized that the first three business strategies (prospector, analyzer and defender) are success strategy due to the consistency and purposefulness of the strategy. In contrast, the reactor was proposed a unsuccess business strategy due to the inconsistency of the strategy.

A large number of studies examined the relationship between business strategy typology of Miles and Snows (1978) and performance. Most of them suggested that performance will be [a] equal among defenders, prospectors and analyzers, and [b] higher than in reactors (Woodside et al., 1999, Conant et al, 1990, Zahra and Pearce, 1990, Smith et al., 1986). Analyzers are not included in this study for keep the argument a more focused and straightforward and (2) due to no analyzers were found in study sample, which mean research hypotheses could not tested anyway.

\subsection{The Implication of Fit Between Natural Environmental Approach and Business Strategy and on Performance: A Theoretical Framework}

Aragon-Correa (1998) defined that each natural environmental approach (Prevention, Information and Correction) has different characteristics and some consequences for the firm to be required. Moreover, Miles and Snow (1968) proposed different characteristics for each Prospector and Defender strategy. Therefore, the congruence between firm's natural environmental approach and business strategy will have positive implications on firm performance.

The theoretical framework presented in Figure 1 integrate logic arguments discussed above to develop a key premise in this paper - that the natural environmental approaches will have a stronger effect on performance among prospectors and defenders. This premise is based on three theoretical relationships

First, prevention approach focuses on activities such as total quality program and product life cycle analysis in relation to environmental aspects. Those activities may lead to the development of new products and designs with minimal negative impact on natural environment. Prospectors are better to apply this approach due to prospectors always analyze all aspects (including natural environmental aspects) of their contexts and grow by developing new products and markets (Miles and Snow, 1968). In relation to firm performance, prevention approach applied by prospectors may lead to produces differentiation advantage that may create the potential to increase product prices, which result in high revenue.

Second, information approach focuses on activities such as marketing, seminar and sponsorship in environmental event. With the characteristic of always sear of new markets (Miles and Snow, 1968), prospectors are better to manage environmental marketing programs. Information approach applied by prospectors may lead to enhance overall reputation or image of the firm that may create the potential to increase sales growth. 
Third, correction approach focuses on activities such as residue recycling and filters and controls on emissions and discharges. In order to apply those activities, the firms need to reinstall their production process and technology to reduce the level of pollution to a certain level that required by environment standard proposed by government. Defenders might well use environmental improvements in technological process to reduce their costs and improve their efficiency, but several reason suggest that prospectors will achieve more natural environmental progress on the production and technological side. First, The prospectors are prepared to invest heavily in order to enhance their technological leadership (Aragon-Correa, 1998). Second, Prospectors have flexible technologies capable of responding quickly to change (Miles and Snow, 1968). Third, Environmental advance technological improvements made by prospectors can be expected to act more quickly (Aragon-Correa, 1998).

These arguments lead to the research hypothesis tested in the study.

Hypothesis 1: Prevention will have a stronger positive effect on organizational performance among prospectors than among defenders.

Hypothesis 2: Information will have a stronger positive effect on organizational performance among prospectors than among defenders.

Hypothesis 3: Traditional will have a stronger positive effect on organizational performance among prospectors than among defenders.

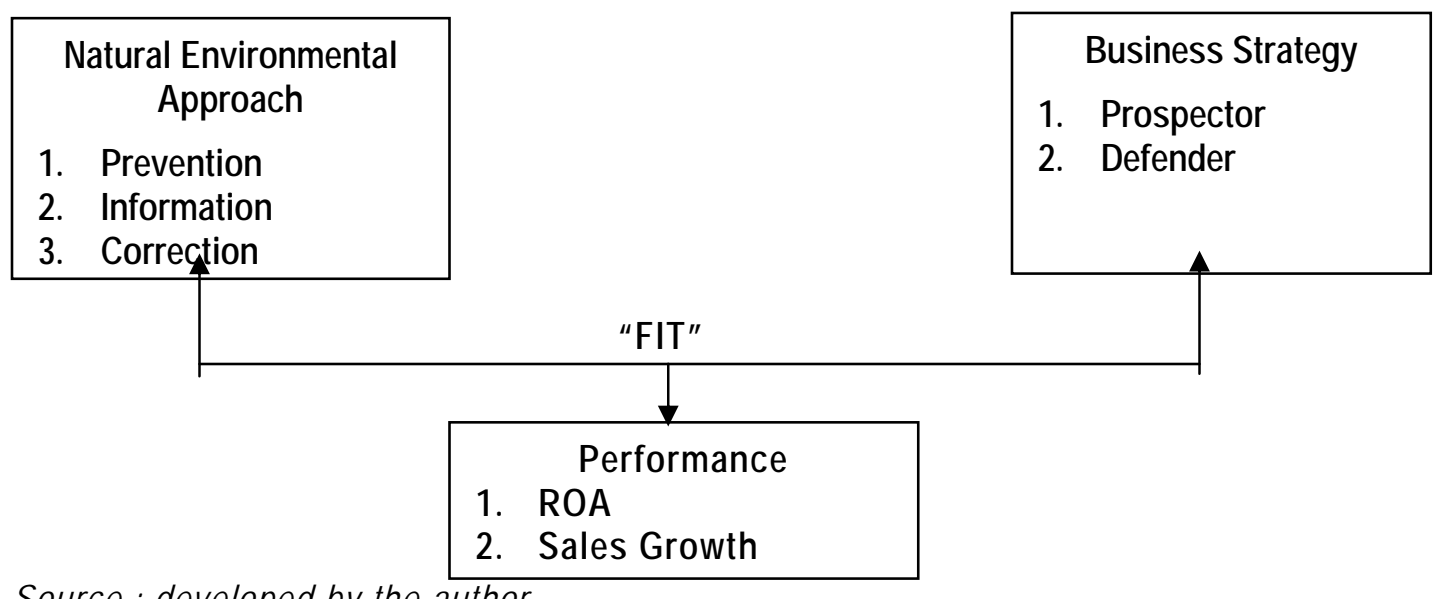

Source : developed by the author

Figure 1

The Implication of Fit between Natural Environment Approach and Business Strategy on Performance: A Theoretical Framework

\section{METHOD}

\subsection{Sample}

To be included in the study, firm had to be a chemical firm. Those firms are included under chemical industry with the two-digit ISIC. In this study, 487 chemical firms in Indonesia were involved as research target. Finally 83 firms among them give feedback response that indicating a 17.04 percent response rate. The final sample and response are presented in Table1.

Indonesian chemical industry contain heavy sources of pollution. According to Resosudarpo et al. (2000). The scores of IEp (Index Pollution effect) of Indonesian chemical industry are 1.33 for Sox and 2.22 for NO2, and 0.60 for TSP. Those figure are more than 1 on average that indicated that chemical industry is the heavy source for air pollution. They also fount that the scores of IEp (Indexs Pollution effect) of Indonesian chemical industries are 12.90 for BOD, and 10.36 for TSS. All those scores also are more than 1 in average that indicated the Indonesian chemical industry is the heavy source for river water pollution. 
Table 1

Detail of Sample Firms and Respondent Rates

\begin{tabular}{|c|c|c|c|c|}
\hline No & Title & $\begin{array}{l}\text { Research } \\
\text { Targets }\end{array}$ & $\begin{array}{c}\text { Response } \\
\text { Rate (\%) }\end{array}$ & Responses \\
\hline \multicolumn{5}{|c|}{ ISIC (Industry Title) } \\
\hline 1 & 24111-24119 (Basic Chemicals) & 100 & 20.00 & 20 \\
\hline 2 & $24121-24129$ (Fertilizers) & 100 & 18.00 & 18 \\
\hline 3 & 24131-24132 (Synthetics) & 87 & 11.40 & 10 \\
\hline 4 & 24212 (Pesticides) & 50 & 30.00 & 15 \\
\hline 5 & 24220 (Paint and Varnishes) & 50 & 14.00 & 7 \\
\hline 6 & 24231-24234 (Pharmaceutical and Drugs) & 20 & 20.00 & 4 \\
\hline 7 & 24241-24242 (Soap and Cosmetics) & 40 & 7.50 & 3 \\
\hline \multirow[t]{3}{*}{8} & 24291-24299 (Adhesive, Ink, Chemical n.e.c). & 40 & 15.00 & 6 \\
\hline & TOTAL & 487 & 17.04 & 83 \\
\hline & Number of Employee & & & \\
\hline 1 & $0 \sim 49$ & 93 & 13.98 & 13 \\
\hline 2 & $50 \sim 99$ & 114 & 16.66 & 19 \\
\hline 3 & $100 \sim-449$ & 180 & 17.29 & 32 \\
\hline 4 & $500 \sim 1000$ & 75 & 20.00 & 15 \\
\hline \multirow[t]{3}{*}{5} & $1000 \sim$ & 25 & 16.00 & 4 \\
\hline & Total & 487 & 17.04 & 83 \\
\hline & Status of Investment Facility & & & \\
\hline 1 & Indigenous & 387 & 16.53 & 64 \\
\hline \multirow[t]{2}{*}{2} & Foreign & 100 & 19.00 & 19 \\
\hline & Total & 487 & 17.04 & 83 \\
\hline
\end{tabular}

Source : Primary Data

\subsection{Measurement and Scaling Design}

3.2.1 Measurement of Business Strategy

In this study, a bundle of questionnaire that consists of 18 question Miles and Snow's strategic dimensions was used to measure the business strategy. The questions were designed to cover the range of business strategy that a firm might adopt. Using seven-point likert scale, possible answers range from 1 to 7 which 1 for "we much worst" and 7 for "we are much better (the best)". Then, the respondent places his or her firm in an appropriate position in the range.

\subsubsection{Measurement of Natural Environmental Approach}

A bundle of questionnaire was used to measure the natural environmental approach. This questionnaire consists of 14 question-related practices, which were adopted from study of Aragon-Correa (1998). Using seven-point likert scale, possible answers range from 1 to 7 as that 1 for "we are not addressed this issue at all and have no plan in the in the future" and 7, for "we are the leader on this in our sector (the best)". Then, the respondent places his or her firm in an appropriate position in the range.

\subsubsection{Measurement of Performance}

Organizational performance was measured using a subjective self-report instrument made up of two scale items. The first scale asked respondent to evaluate the Return on Asset (ROA) of organization relative to their competitors. The second scale item asked respondents to evaluate their organizational performance in reference to a specific measure of sales growth. The seven-point likert scale was used to measure the organizational performance compare with other firm in the industry. The response option for both scale range from 1 to 7 that 1 indicates much worst and 7 indicates much better. Then, the respondent places his or her firm in an appropriate position in the range.

\subsubsection{Measuring of Control Variable}


The size of the firm in the study vary in size suggests the need for control for size. The size indicator used is the number of employee of the firms. Number of employee is one of the more common methods of measuring organizational size (Smith et al 1986)

\section{FINDINGS AND DISCUSSION}

\subsection{Natural Environmental Approach}

In order to develop the natural environmental approach, each firm's standardized scores on 14 natural environmental items defined in Table 2 were subjected to principal component analysis. The items are factor analyzed to capture the correlation between them and analyze whether it was possible to reduce the number of environmental positioning variables. A standardized varimax rotation resulted in three significant factors (with Eugenvalues greater than 1) that together explained a 65.983 percent of variance. Thirteen of the variables exhibited a factor loading of more then .5 on at least one factor; Dess and Davis (1984) regarded such a value as very significant.

Table 2

Factor Loading of Natural Environmental Items

\begin{tabular}{|c|c|c|c|}
\hline Natural Environmental Items & $\begin{array}{l}\text { Factor } 1 \\
\text { Prevention } \\
\text { Approach }\end{array}$ & $\begin{array}{c}\text { Factor } 2 \\
\text { Information } \\
\text { Approach }\end{array}$ & $\begin{array}{l}\text { Factor } 3 \\
\text { Correction } \\
\text { Approach }\end{array}$ \\
\hline $\begin{array}{l}\text { V1. Sponsorship of natural environmental } \\
\text { event }\end{array}$ & & .768 & \\
\hline $\begin{array}{l}\text { V2. Use of environmental argument in the } \\
\text { marketing }\end{array}$ & & .733 & \\
\hline $\begin{array}{l}\text { V3. Natural environmental aspects in the } \\
\text { administrative work }\end{array}$ & & .683 & .434 \\
\hline $\begin{array}{l}\text { V4. Periodic natural environmental audits } \\
\text { V5. Residue recycling }\end{array}$ & & .475 & $\begin{array}{l}723 \\
.758\end{array}$ \\
\hline $\begin{array}{l}\text { V6. Purchasing manual with ecological } \\
\text { guideline }\end{array}$ & .765 & & \\
\hline $\begin{array}{l}\text { V7. Natural environmental seminar for } \\
\text { executive }\end{array}$ & .749 & .408 & \\
\hline $\begin{array}{l}\text { V8. Natural environmental training in for firm's } \\
\text { employee }\end{array}$ & .497 & & .579 \\
\hline $\begin{array}{l}\text { V9. Total quality program with natural } \\
\text { environmental aspect }\end{array}$ & .770 & & .406 \\
\hline V10. Pollution damage insurance & .494 & .493 & \\
\hline $\begin{array}{l}\text { V11. Natural environmental management } \\
\text { manual for internal use }\end{array}$ & .530 & & .446 \\
\hline $\begin{array}{l}\text { V12. Filters and controls on emissions and } \\
\text { discharges }\end{array}$ & & & .749 \\
\hline $\begin{array}{l}\text { V13. Natural environmental analysis of product life } \\
\text { cycle }\end{array}$ & .746 & & \\
\hline $\begin{array}{l}\text { V14. Participation in government-subsidized } \\
\text { environmental programs }\end{array}$ & .408 & .656 & \\
\hline $\begin{array}{l}\text { Eigenvalue } \\
\text { Percentage of variance explained }\end{array}$ & $\begin{array}{r}6.659 \\
47.565\end{array}$ & $\begin{array}{r}1.440 \\
10.283\end{array}$ & $\begin{array}{l}1.139 \\
8.134\end{array}$ \\
\hline
\end{tabular}


Results indicated that the 14 natural environmental practices could be grouped into three approaches. Some variables with high loading on factor 1 were V6 (purchasing manual with ecological guidance), V7 (natural environmental seminar for executives), V9 (total quality program with natural environmental aspect), V11 (environmental management manual for internal use), and V13 (natural environmental analysis of product life cycle). On factor 2, high loading items were, V1 (sponsorships on natural environmental events), V2 (use of natural environmental arguments in marketing), V3 natural environmental aspect in administrative works), and V14 (participation in government-subsidized natural environmental programs). On factor 3 , high loading items were $\mathrm{V} 4$ (periodic natural environmental audit), V5 (residue recycling), V8 (natural environmental training for firm's employees), and V12 (filters and controls on emissions and discharges).

This discussion of factor loading is useful for interpreting approaches. Given the results, greater emphasis was placed on variables with higher loadings and a label was assigned for each approach depicting it as accurately as possible. Factor 1 was labeled as prevention approach, factor 2 as information approach, and factor 3 as correction approach. Table 2 provides the factor loadings of natural environmental items for the final sample of 82 observations (1 observation was dropped due to incomplete data)

\subsection{Business Strategy}

As well as environmental policy variables, each firm's standardized scores on the 18 business strategy variables defined in Table 3, were subjected to principal component analysis. The author factor analyzed the items to capture the correlation between them and analyzed the items to determine whether it was possible to reduce the number of business strategy variables. A varimax rotation of factor analysis produced four significant factors, with eigenvalues greater than 1 that together explained a $59.127 \%$ of total variance. Fourteen of the variables exhibited factor loading of more then the absolute value of 0.50 on at least one factor; Dess and Davis (1984) regarded such a value as common and very significant.

Results indicated that the eighteen business strategy practices could be grouped into four approaches. Some variables with high loadings on factor 1 are V8 (the technology breadth of the firm), V17 (The procedure of the control system in the firm), and V18 (the form of coordination mechanism in the firm). The high loading items on factor 2 were, V1 (the field within which the firm currently conducts its business), V2 (the capacity to monitor environment conditions, trends, and events of the firm), V4 (the firm's success posture in the industry), and V12 (the tenure of member of domain coalition in the firm). On factor 3, high loading items were, V10 (the competencies (skill), which firm's employees possess), V11 (the domain-coalition of the firm), and (planning in the firm). Finally, on factor 4 , items with high loading were V3 (the stability of customer base of the firm), V5 (the pattern of the firm's growth), V9 (the degree of routinization and mechanization of the firm's production process), V15 (the extensive division of labor in the firm) and V16 (the degree of structural formalization in the firm). Then each factor is labeled based on high loading variables. Factor 1 was labeled as technology and coordination, factor 2 as business expansion, factor 3 as competency and planning, and factor 4 as customer focus. Table 3 provides the factor loadings of business strategy items for the final sample of 79 observations (4 observations were dropped due to incomplete data)

The score of all four factors of business strategy were then calculated and subjected to cluster analysis. The result was obtained by applying a non-hierarchical procedure known as kmeans cluster to the number of groups to be adopted to Miles and Snow (1978) definition. The F Statistic was noted for each level of clustering and the appropriate number of clusters was identified on the basis of the inflection points in these statistics. Tukey's tests for multiple comparisons of means were then used to examine pairwise differences among the clusters along the four factors. Table 4 describes the three clusters identified through the k-means clustering algorithm. 
Table 3.

Factor Loading of Business Strategy Items

\begin{tabular}{|c|c|c|c|c|}
\hline Business strategy Items & $\begin{array}{l}\text { Factor } 1 \\
\text { Technology } \\
\text { and } \\
\text { Coordination }\end{array}$ & $\begin{array}{c}\text { Factor } 2 \\
\text { Business } \\
\text { Expansion }\end{array}$ & $\begin{array}{l}\text { Factor } 3 \\
\text { Competency } \\
\text { and } \\
\text { Planning }\end{array}$ & $\begin{array}{l}\text { Factor } \\
\text { Customer } \\
\text { Focus }\end{array}$ \\
\hline $\begin{array}{l}\text { V1. The field within which the firm } \\
\text { currently conduct it business }\end{array}$ & & 826 & & \\
\hline $\begin{array}{l}\text { V2. The capacity to monitor } \\
\text { environment conditions, trends, } \\
\text { and events of the firm }\end{array}$ & .432 & .582 & & \\
\hline $\begin{array}{l}\text { V3. The stability of customer base of the firm } \\
\text { V4. The firm's posture in the industry }\end{array}$ & & .607 & & .708 \\
\hline $\begin{array}{l}\text { V5. The pattern of the firm's growth } \\
\text { V6. The attitude toward growth of the firm }\end{array}$ & .419 & & & -.438 \\
\hline $\begin{array}{l}\text { V7. The main focus of concern in } \\
\text { relation to the firm's technological } \\
\text { process } \\
\text { v8. The technological breadth of the } \\
\text { firm }\end{array}$ & .417 & & .478 & \\
\hline $\begin{array}{l}\text { V9. The degree of routinization and } \\
\text { mechanization of the firm's } \\
\text { production possess }\end{array}$ & & -.470 & & .576 \\
\hline $\begin{array}{l}\text { V10. The competencies (skill), which } \\
\text { firm's employees process }\end{array}$ & & & .796 & \\
\hline V11. The domain-coalition of the firm & & & .759 & \\
\hline $\begin{array}{l}\text { V12. The tenure of members of the domain- } \\
\text { coalition in the firm }\end{array}$ & & 699 & & \\
\hline $\begin{array}{l}\text { V13. Planning in the firm } \\
\text { V14. The nature of structure of the firm }\end{array}$ & .431 & & .585 & -.425 \\
\hline $\begin{array}{l}\text { V15. The extensive division of labor in } \\
\text { the firm }\end{array}$ & & & & .672 \\
\hline $\begin{array}{l}\text { V16. The degree of structural } \\
\text { formalization in the firm }\end{array}$ & & & & .690 \\
\hline $\begin{array}{l}\text { V17. The procedure of the control } \\
\text { system in the firm }\end{array}$ & .629 & & & \\
\hline $\begin{array}{l}\text { V18. The form of coordination } \\
\text { mechanism in the firm }\end{array}$ & .814 & & & \\
\hline Eigenvalue & 4.763 & 2.306 & 1.957 & 1.617 \\
\hline Percentage of variance explained & 26.416 & 12.811 & 10.872 & 8.983 \\
\hline
\end{tabular}

Source : Primary Data

Cluster 1 firms scored the highest among all three clusters on business expansion and technology and coordination. They were the most innovative firms in the sample in the matter of business, technology and administration. Consistent with Miles and Snow (1978) typology, the 23 firms in this cluster were called Prospector. Cluster 2 firms scored the highest among all three clusters on customer focus and competency and planning. They put emphasis on protecting their 
base business. Moreover, they also emphasized on planning process formality and reaching technical efficiency. Consistent with the description of such firm in Miles and Snow (1987) typology, the 34 firms in cluster 2 were labeled Defender. Cluster 3 firms displayed no consistent pattern in their strategies. They scored the lowest among all three clusters on business expansion, competency and planning, and technology and coordination. Hence the 22 firms in this cluster were called Reactor.

Table 4.

Business Strategy Clusters

$\begin{array}{rrrr}\text { Cluster 1 } & \text { Cluster 2 } & \text { Cluster } & \text { F-Value } \\ \text { Prospector } & \text { Defender } & 3 & \\ & & \text { Reactor } & \end{array}$

Factor score 1:Technology and Coordination

Factor score 2: Business Expansion

Factor score 3: Competency and Planning

Factor score 4: Customer Focus

Number of cases

$.78327 \quad .19504 \quad-1.63697 \quad 30.075$

Source : Primary Data

\subsection{The Implication of Fit between Environmental Approach and Business Strategy on Performance}

In this study, multiple regression analysis will be used to find out the effect of fit between business strategy types and environmental approaches on organizational performance. The organizational performance (ROA or sales growth) serving is as dependent variable of the regression. Two dummy variables are created here to represent the Prospector Strategy (PS) and Defender Strategy (DS), while reactor serving as the base case. Three environmental approaches to be regressed here are: Prevention Approach (PA), Information Approach (IA), and Correction Approach (CA). Finally, there are six interaction variables that produced from multiplication between two business strategies and three environmental approaches. The proposed relationship among those variables can be summarized in the multiple regression equation.

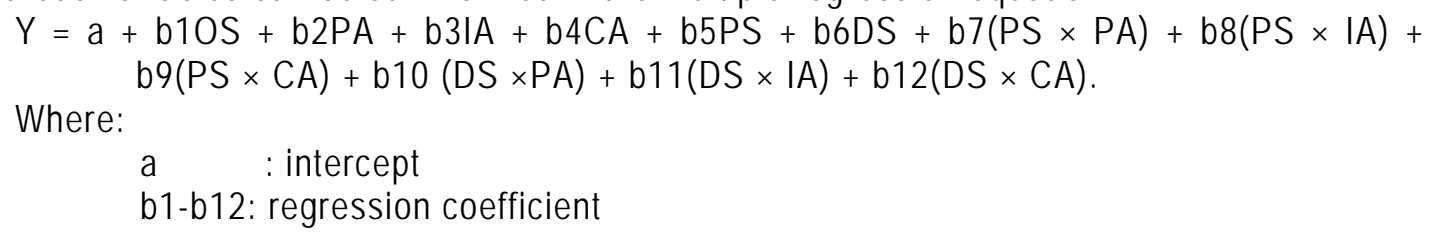

Before doing the regression analysis, all of the variables described above were subjected to correlation analysis to find out the inter-correlation among variables in the study. Moreover, there are two regression models developed here due to two alternative dependent variables that were measured: ROA and sales growth. Table 5 provides the unstandardized coefficients, standard errors, and $t$ values for all independent variables for the sample of seventy-nine observations (four observations were dropped due to incomplete data). The F-statistic and Rsquare regression model are also presented in this table.

The regression analysis reported that the three environmental approaches insignificantly affected both organizational performances: ROA and sales growth. Compared to reactors, defenders and prospectors realized significant improvements in both performance measures. The coefficient score on defender indicates the differences between defenders and reactors. Both regression models report that defenders have higher score than reactors about 2.090 on ROA and 
0.830 on sales growth. The same as defenders, the coefficient for the prospector variable indicates differences between prospectors and reactors. Both regression models are reported that prospectors have higher score than reactors about 2.266 on ROA and 1.236 on sales growth.

Hypothesis 1 predicted that prevention will have a stronger effect on organizational performance among prospectors than among defenders. This hypothesis was supported only for ROA. The interaction term of prospector and prevention was positive and significant in 1 percent while corresponding interaction term for defenders was not significant. However, this result did not hold for the sales growth. The both interaction variables (defender $x$ prevention and prospector $x$ prevention) did not have significant effect on sales growth.

Hypothesis 2 predicted that the information will have stronger effect on organizational performance among prospectors than among defenders. This hypothesis was supported for both ROA and sales growth. In terms of ROA, the interaction term of prospector and information was positive and significant in 5 percent while corresponding interaction term for defenders was not significant. In terms of sales growth, the both interaction variables (defenderx information and prospector $x$ information) were significant in 0.1 percent and 1 percent respectively. However, the interaction term of defender and information scored higher than the interaction term of defender strategy and information.

Hypothesis 3 predicted that the correction will have stronger effect on organizational performance among prospectors than among defenders. This hypothesis was not supported for ROA and sales growth. Both interaction variables (defender $x$ correction and prospector $x$ correction) were not significant.

Table 5

Results of Regression Analysis

\begin{tabular}{|c|c|c|c|c|}
\hline & \multicolumn{2}{|c|}{ ROA } & \multicolumn{2}{|c|}{ Sales Growth } \\
\hline & $\begin{array}{l}\text { Unstandar } \\
\text { Coefficient } \\
\text { (Standard }\end{array}$ & t-value & $\begin{array}{l}\text { Unstandardized } \\
\text { Coefficients B } \\
\text { (Standard Error) }\end{array}$ & t-value \\
\hline (Constant) & $\begin{array}{l}2.705^{* * *} \\
(0.606)\end{array}$ & 4.483 & $\begin{array}{l}3.229 * * \star \\
(0.515)\end{array}$ & 6.411 \\
\hline $\begin{array}{l}\text { Logarithm of Organizational } \\
\text { Size }\end{array}$ & $\begin{array}{l}0.080 \\
(0.260)\end{array}$ & 0.309 & $\begin{array}{l}0.039 \\
(0.222)\end{array}$ & 0.175 \\
\hline Prevention & $\begin{array}{l}0.039 \\
(0.190)\end{array}$ & 0.206 & $\begin{array}{c}0.115 \\
(0.162)\end{array}$ & 0.709 \\
\hline Information & $\begin{array}{l}-0.248 \\
(0.184)\end{array}$ & -1.350 & $\begin{array}{l}-0.442 \\
(0.157)\end{array}$ & -2.692 \\
\hline Correction & $\begin{array}{l}0.095 \\
(0.175\end{array}$ & 0.554 & $\begin{array}{c}0.250 \\
(0.147)\end{array}$ & 1.705 \\
\hline Defender Strategy & $\begin{array}{l}2.090 * * * \\
(0.267)\end{array}$ & 7.822 & $\begin{array}{l}0.830^{* *} \\
(0.252)\end{array}$ & 3.301 \\
\hline Prospector Strategy & $\begin{array}{l}2.266^{* * *} \\
(0.295)\end{array}$ & 7.690 & $\begin{array}{l}1.236^{* * *} \\
(0.228)\end{array}$ & 5.426 \\
\hline Defender $\times$ Prevention & $\begin{array}{l}0.221 \\
(0.248)\end{array}$ & 0.891 & $\begin{array}{l}0.042 \\
(0.258)\end{array}$ & 0.165 \\
\hline Defender $\times$ Information & $\begin{array}{c}0.327 \\
(0.276)\end{array}$ & 1.184 & $\begin{array}{l}0.689^{* *} \\
(0.236)\end{array}$ & 2.892 \\
\hline Defender $\times$ Correction & $\begin{array}{l}-0.225 \\
(0.242)\end{array}$ & -0.075 & $\begin{array}{l}-0.013 \\
(0.206)\end{array}$ & -0.065 \\
\hline Prospector $\times$ Prevention & $\begin{array}{l}0.899 * * \\
(0.303)\end{array}$ & 2.971 & $\begin{array}{l}0.169 \\
(0.236)\end{array}$ & 0.799 \\
\hline
\end{tabular}




\begin{tabular}{lllll}
\hline & \multicolumn{1}{c}{$\begin{array}{c}\text { ROA } \\
\text { Unstandardized } \\
\text { Coefficients B } \\
\text { (Standard Error) }\end{array}$} & t-value & $\begin{array}{l}\text { Sales Growth } \\
\text { Unstandardized } \\
\text { Coefficients B } \\
\text { (Standard Error) }\end{array}$ & t-value \\
\hline $\begin{array}{l}\text { Unstandardized Coefficients } \\
\text { B (Standard Error) }\end{array}$ & t-value & $\begin{array}{l}\text { Unstandardized } \\
\text { Coefficients B } \\
\text { (Standard }\end{array}$ & & 3.723 \\
t-value & \\
Prospector ×Correction & -0.251 & Error) & & -0.651 \\
Model F-Statistic & $(0.299)$ & -1.038 & -0.166 & \\
Model R squared & $8.822 * * *$ & & $0.255)$ & \\
\hline
\end{tabular}

Note: * Significant level $p<0.05$

** Significant level $p<0.01$

*** Significant level $p<0.001$

Source: Regression EstimationResults

\section{CLOSING REMARKS}

\subsection{Conclusion and Policy Implication}

The factor analysis indicated three natural environmental approaches: prevention, information and correction, adapted in the Indonesian chemical industry. The dimensions of natural environmental approach identified confirm the common distinction between traditional (relates to correction) and modern method (relates to the prevention). The businesses have to be considered that two dimension had different characteristics, resulting in specific organizational implications and requirements. The results also proved the occurrence of the information. It indicated the importance of the variables covered by this factor for the achievement of natural environmental progress. The high loading of natural environmental programs prepared by government indicated that government has a significant role in promoting natural environmental aspect to the firms. The absolute minimum is two factors, one for measuring the positions of groups on the correction approach, the other for measuring their positions on the prevention approach. Intermediate categories can be described particularly well on this basis.

The results from regression analysis support to the statement that the more advance business strategy the more advance environmental approach especially in the matter of prevention and information approach. Moreover, the natural environmental approaches will have a stronger effect on performance among prospectors and defenders.

\subsection{Limitations of the Study and Suggestions for the Future Research}

Interpretation of the results presented in subject to limitations. First, the small number of usable responses makes it difficult to generate general conclusion. Second, the risk involved in converting verbal classification scales into interval scale. Third, most of the sample firms were medium to large, and it is possible that fewer responses were received from small firms with less developed environmental postures. Although this possibility did not prevent verification of the hypotheses formulated, the better representation of the positions of the firms analyzed needs emphasizing for the future research. Finally, Objective data on environmental performance of the firms were not available in this study. Further research is required to study the impact of the relationship discussed on this variable, because business strategy could moderate the relationship between firms' environmental performance and profitability. 


\section{REFERENCES}

Aragon-Correa, J.A., (1998), Strategic Proactivity and Firm Approach to the Natural Environment, Academic of Management Journal, Vol. 41, No. 5, pp. 556-567.

Cristmann., P., (2000), Effects of Best Practices of Environmental Management on Cost Advantage: The Role of Complementary Assets, Academy of Management Journal, Vol. 43 No. 4, pp. 663-680.

Dess G.S., and Robinson, Jr., RB., (1984), Measuring Organizational Performance in Absence of Objective Measures, Strategic Management Journal, Vol. 11 (July-September), pp. 365-383.

Grant, R.M., (1991), The Resource-Based Theory of Competitive Advantage: Implications for Strategic Formulation, California Management Review, Spring, pp. 114-135.

Hart, S.L., (1995), A Natural Resource-Based View of the Firm, Academic of Management Review, Vol. 20, No. 4, pp. 986-1014.

Henriques, I., and Sadorsky, P., (1999), The Relationship between Environmental Commitment and Managerial Perception of Stakeholder Importance, Academy of Management Journal, 42 No. 1, pp. 8799.

Klassen R.D., and Shook C L., (1996), The Impact of Environmental Management on Firm Performance, Management Science, Vol. 42, No. 8, pp. 1199-1213.

Menon, A. and Menol, A., (1997), Enviropreneurial Marketing Strategy: The Emergence of Corporate Enviromentalism as Market Strategy, Journal of Marketing, Vol. 61, pp. 51-67.

Miles, R.E., and Snow,C.C., (1978), Organizational Strategy, Structure and Process, McGraw-Hill Book Company.

Porter, M.E., (1995), Green and Competitive: Ending The Stalemate, Harvard Business Review, SeptemberOctober: 120-134.

Resosudarmo, B.P., Mahi B.R., Kuncoro, A., Handayani, S.B., (2000), Emisi Polusi Udara dan Air Sungai Dalam Struktur Industri Indonesia, Jurnal Ekonomi Lingkungan, June: 47-73.

Roome, N., (1994), Business Strategy, R\&D Management and Environmental Imperatives, R\&D Management, Vol. 24, No. 1: 65-82.

Russo, M.V., (1997), A Resource-Based Perspective on Corporate Environmental Performance and Profitability, Academy of management Journal, Vol. 40, No. 3: 534 - 559.

Sharma, S., and Vredenburg, H., (1998), Proactive Corporate Environmental Strategy and the Development of Competitively Valuable Organizational Capabilities, Strategic Management Journal, Vol. 19: 727 - 759.

Shrivastava, P., (1995), The Role of Corporation n Achieving Ecological Sustainability, Academy of Management Review, Vol. 20, No. 4: 936 - 960 
Slater, J. and Angel, I.T., (2000), The Impact and Implications of Environmentally Linked Strategies on Competitive Advantage: A Study of Malaysian Companies, Journal of Business Research, Vol. 47: 75 89.

Starik, M., and Rands, G.P., (1995), Weaving An Integrated WEB: Multilevel and Multisystem perspectives of Ecologically Sustainable Organizations, Academy of management Review, Vol. 20, No. 4: 908 - 935.

Suprapto, B., (2004), Business Strategy, Environmental Policy and Organizational Performance: A Study of Indonesian Chemical Industry, Proceedings of GRONEN Workshop 2004, t7-5: 1-27.

Woodside, A.G., Sullivan, D.P., and Trappey III, R.J., (1999), Assessing Relationships Among Strategic Types, Distinctive Marketing Competencies, and Organizational Performance, Journal of Business Research, Vol. 45, No. 2: 135-146.

Zahra, S.A., and Pearce II J.A., (1990), Research Evidence on The Miles-Snow Typology, Journal of Management, Vol. 16, No. 4: 751-768. 